Jpn. J. Oral Biol., $38:$ 587-597, 1996.

原著

\title{
老化促進モデルマウス（SAM）の舌粘膜上皮の 加齢的変化に関する病理学的検討
}

\author{
守田裕 啓 佐島 三重子 \\ 岩手医科大学歯学部口腔病理学講座 (主任：佐藤方信教授) \\ 〔受付: 平成 8 年 5 月 31 日, 受理 : 平成 8 年 9 月 5 日〕
}

Histopathological study on age-related changes of the tongue epithelium
in senescence accelerated mouse (SAM)

Hiroaki Morita and Mieko Sashima

Department of Oral Pathology, School of Dentistry, Iwate Medical University
(Chief : Prof. Masanobu Satoh)
19-1 Uchimaru, Morioka 020, Japan

(Received on May 31, 1996 ; Accepted on September 5, 1996)

Key words : tongue/epithelium/aging/senescence accelerated mouse/pathology

\begin{abstract}
The age-related changes of the tongue epithelium of SAMR1/Iw as a control group, and SAMP2/Iw as an experimental group, were studied by morphometry. SAMP2/Iw showed a greater number of epithelial rete pegs than SAMR1/Iw at 2 and 16 months of age. This difference was signifcant in the lateral and the ventral mucosa at 2 months of age, and in the ventral mucosa at 16 months of age, respectively $(p<0.05)$. The number of tongue papillae did not differ among age groups in either SAM strains. The epithelial thickness at the rete pegs was greater in SAMP2/Iw than in SAMR1/Iw at 2 and 16 months of age. This difference was significant in the dorsal and the ventral mucosa at 16 months of age $(p<0.05)$. The epithelial thickness at the papillae was constant through all age groups in both SAM strains. The number of PCNA (proliferating cell nuclear antigen) positive epithelial cells in SAMR1/Iw did not differ among age groups. In contrast, SAMP2/Iw had a large number of PCNA positive cells at 2 months of age. The difference between SAMP2/Iw and SAMR1/Iw at 2 months of age, and between 2 months of age and other age groups in SAMP2/Iw was significant $(p<0.01)$. Morphometry and immunohistochemistry of the tongue suggested indicated that epithelial cell proliferation was accelerated or some other growth hormone was rich in SAMP2/Iw at 2 months of age.
\end{abstract}

抄録：老化促進モデルマウスの SAMP2/Iw（実験群）と SAMR1/Iw（対照群）の舌粘膜上皮の加齢に伴う変 化を組織計量学的に検討した。上皮突起数は 2 カ月と 16 カ月齢で SAMP $2 / \mathrm{Iw}$ が SAMR1/Iw より多く, 特に 2 力月齢では㗹側縁と舌下面, 16 力月齢では舌下面で有意差がみられた $(\mathrm{p}<0.05)$ 。舌乳頭数は両系統とも加齢 による変化は明らかでなかった。上皮の厚さは上皮突起部では 2 カ月と 16 カ月齢で SAMP $2 / \mathrm{Iw}$ が SAMR $1 / \mathrm{Iw}$

厂 020 岩手県盛岡市内丸 19-1 
より厚かった。特に 16 カ月齢では舌背と舌下面で有意差がみられた $(\mathrm{p}<0.05)$ 。上皮乳頭部では両系統とも加齢 による変化はなかった。抗 proliferating cell nuclear antigen (PCNA) 抗体による上皮細胞の免疫染色では, $\mathrm{SAMR} 1 / \mathrm{Iw}$ では加齢によっても陽性細胞数が一定であった。SAMP2/Iwでは 2 力月齢で最も多く, 同月齢の $\mathrm{SAMR} 1 / \mathrm{Iw}$ との間にも，また SAMP2/Iw の他の月齢群との間にも有意差がみられた $(\mathrm{p}<0.01)$ 。 SAMP2/Iw の 2 力月齢では組織計量学的所見と PCNA 陽性細胞数が多いことから，この月齢の舌粘膜上皮細胞は増殖能が 高いか, 何らかの成長因子が影響している可能性が示唆された。

\section{緒 言}

一般に老人の口腔粘膜上皮には菲薄化と萎縮がみら れ, 組織学的にも加齢に伴って上皮突起が短縮したり, 上皮が平坦化することが知られている1。舌粘膜におい ては加齢に伴って上皮突起の形，長さ，配列などが不規 則になり ${ }^{2)}$, 舌背では糸状乳頭の萎縮およびその長さや 配列が不規則となったり，あるいは全く消失する例もあ る や，種々の病態変化について報告してきた。

一方, 近交系の老化促進モデルマウス (senescence accelerated mouse, 以下 SAM と略）には種々の老化兆 候が軽度で緩徐に出現する resistant 系 (SAMR) と, 老化兆候が早期に好発する prone 系 (SAMP) とがそれ

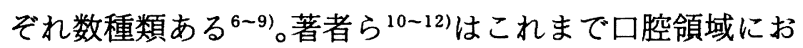
ける老化研究のモデル動物として, SAM の有用性を検 討してきた。SAMP2/Iw (prone 2/Iwate) には，加齢 とともに舌などの口腔粘膜にアミロイドが沈着すること を報告した ${ }^{11)}$ 。また, SAMP2/Iw の舌動脈壁に特有の微 細顆粒状物質がみられ，これが加齢に伴って増加してい ることから自然発生的動脈硬化症の初期像を示唆する所 見として報告した ${ }^{12)}$ 。

老齢期における舌粘膜の菲薄化や萎縮の原因の 1 つと して, 加齢による上皮細胞の増殖能の減退が考えられ る ${ }^{13)}$ 。しかし，ヒトおよび実験動物において，これらに関 する結論は得られていない(14)。すなわち, 加齢に伴う舌粘 膜上皮細胞の増殖能に関しては, 六進するという報告, 低下するという報告, あるいは変化がないとする報告が あり,これまでに定説はない ${ }^{14)}$ 。最近では分裂細胞数を算 定したり, ${ }^{3} \mathrm{H}$ (トリチウム)-サイミジンによるラベリン グに代わって免疫組織化学的に增殖細胞を検出する方法 が開発されている ${ }^{15)}$ 。この 1 つに増殖細胞核抗原 proliferating cell nuclear antigen（以下 PCNA と略） がある ${ }^{16)}$ PCNA は cyclin ともよばれる非ヒストン核 蛋白質（分子量 $36 \mathrm{kD}$, 等電点 4.8) で, 増殖サイクルの 主として $\mathrm{G} 1$ 後期から $\mathrm{S}$ 期にかけて細胞核内に蓄積し, DNA ポリメラーゼ $\delta$ の補助因子として DNA 合成に関
与することが知られている ${ }^{15,16)}$ 。今日，PCNA は増殖サ イクルのマーカーとして腫場細胞の増殖能の検定などに 繁用されている ${ }^{17)}$ 。

著者らは SAM の舌粘膜上皮の加齢変化を解明する目 的で, 舌粘膜の上皮突起数, 舌乳頭数, また, 上皮突起 部および乳頭部における上皮の厚さを組織計量学的に検 索した。さらに，上皮細胞の増殖動態を抗 PCNA 抗体 を用いた免疫組織化学的染色によって検索し, PCNA 陽 性細胞数を求めた。上記の組織学的パラメーターについ て，SAM の系統による差および月齢による差を統計的 に処理し, 加齢との観点から比較検討した。

\section{材料および方法}

\section{1. 実験動物}

実験に用いた老化促進モデルマウスは岩手医科大学動 物実験センターにおいて繁殖飼育した種々の月齢の SAMR1/Iw (senescence accelerated mouse resistant 1/Iwate) (対照群) と SAMP2/Iw (senescence acceler ated mouse prone $2 /$ Iwate) (実験群) である。なお，以 下の実験は「岩手医科大学における動物実験に関する指 針」に基づいて行った。両系統の SAM は通常状態で水 道水と固形飼料 (CE-2, 日本クレア) の自由摂取で維持 された。SAMR1/Iw および SAMP2/Iw の平均寿命は それぞれ 13.6 力月および 9.6 カ月であった ${ }^{10)}$ 。両系統の SAMを 1，2，6，12 および 16 力月齢群に分け， $\mathrm{SAMR} 1 / \mathrm{Iw}$ については 24 力月齢も検索した。各月齢群 は10匹（雌雄各 5 匹）を検索対象とした。なお，SAMP $2 / \mathrm{Iw}$ は平均寿命が短いこともあり，24 カ月齢のマウス は十分な例数を収集できなかった。

\section{2. 病理組織学的観察}

各月齢群の SAM をエーテル麻酔下で屠殺し, 舌を摘 出した。また, 屠殺時間帯は午前 9 時頃とした。舌は $10 \%$ 燐酸緩衝ホルマリン液で固定し, 舌の中央部から前額断 で組織を切り出し, 通常の方法でパラフィン包埋をした。 $4 \mu \mathrm{m}$ の準連続切片を作製し，へマトキシリン・エオジン 染色（以下 $\mathrm{H} ・ \mathrm{E}$ 染色と略）をして組織学的に観察した。 


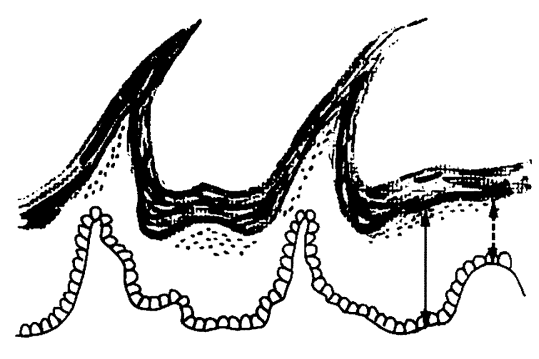

Dorsal mucosa

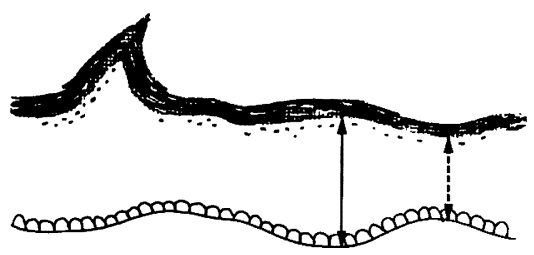

Lateral mucosa

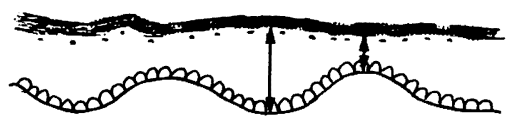

Ventral mucosa

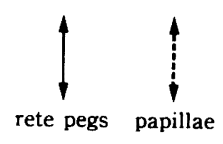

Fig. 1 Schema of the measuring points of epithelial thickness at the rete pegs and at the papillae.

また，一部の標本はコンゴー赤染色を行った。組織計測 は舌の左側粘膜を舌背, 舌側緑, 舌下面の 3 部位に分け て行った。粘膜表面長 $1.0 \mathrm{~mm}$ あたりの上皮突起数およ び糸状乳頭を主とした舌乳頭数を接眼レンズ $(\times 10)$ に ミクロメーターを装着し, 対物レンズ 10 倍の顕微鏡下に おいて算定した。舌側縁の部位は上皮乳頭の形成がみら れない点を中心に舌背と舌下面方向に粘膜表面長 0.5 $\mathrm{mm}$ ずつの範囲とした。また，同じく舌の 3 部位で上皮 突起部と上皮乳頭部における呫粘膜上皮の厚さをミクロ メーターを装着した接眼レンズ $(\times 10)$ を用い，対物レ ンズ 20 倍の顕微鏡下で測定した (Fig. 1)。測定の範囲は 基底層から顆粒層までとし，角質層は除いた。SAM の 1 個体あたりそれぞれ 3 力所で測定し，その個体の值とし た。

\section{3. 免疫組織化学的観察}

免疫組織化学的染色は $4 \mu \mathrm{m}$ のパラフィン切片を用 い，キシレンにて脱パラフィン後，アルコール系列にて 脱水し， $0.05 \mathrm{M}$ リン酸緩衝食塩水（以下 PBS と略）に
て 5 分間 3 回洗浄した。内因性のペルオキシダーゼを除 去するために，これを $0.3 \% \mathrm{H}_{2} \mathrm{O}_{2}$ 加メタノール溶液に 20 分間浸漬した。そしてPBS にて 5 分間 3 回洗浄後, ヤギ正常血清により 30 分間室温で非特異反応をブロッ キングした（1 次抗体以外は Pathostain ABC キット, 和光を用いた)。1 次抗体として抗 PCNA モノクローナ ル抗体 $(5 \mathrm{~A} 10, \mathrm{MBL})$ を 250 倍に希釈して用い, 室温に て 30 分間反応させた。2 次抗体はビオチン標識ヤギ抗マ ウス IgG 抗体を用い, 室温にて 30 分間反応させた。酵 素試薬はペルオキシダーゼ標識ストレプトアビジンを 20 分間室温で反応させた。発色には $0.02 \%$ Diaminobenzidine (DAB) 溶液 $(0.05 \mathrm{M}$ トリス緩衝液 $\mathrm{pH} 7.6)$ を用い，核染色は $1 \%$ ×ル緑 $(\mathrm{pH} \mathrm{4.0)}$ で行っ た ${ }^{18)}$ 。

舌粘膜上皮細胞における PCNA 陽性細胞は顕微鏡下 で強陽性, 中等度陽性, 弱陽性の 3 段階に分け, 強陽性 および中等度陽性の細胞を陽性と判定した。舌背, 舌側 緑, 舌下面の 3 部位について, 画像解析装置 (IBAS-2000, カールツァイス）を用いて呫粘膜上皮の表面長 $1.0 \mathrm{~mm}$ あたりの PCNA 陽性細胞数を求めた。

\section{4. 統計学的処理}

舌粘膜上皮の上皮突起数, 舌乳頭数および上皮突起部 と乳頭部における舌粘膜上皮の厚さのそれぞれの測定值 について各系統および各月齢群 10 匹の平均值を求めた。 SAM の両系統間における差および月齢群による差を統 計学的に処理し (分散分析, Newman-Kewl test), 加齢 との観点から比較検討した。

同様に PCNA 陽性細胞数について SAM の両系統間 における差および月歯群による差を統計学的に処理し (分散分析, Newman-Kewl test), 加跲との観点から比 較検討した。

\section{成 績}

\section{1. 病理組織学的所見}

舌背の上皮細胞は SAMR1/Iw の 2 カ月齢では，規則 正しく配列し，上皮突起と乳頭も規則的に配列していた (Fig. 2-A)。また, 舌背には多数の糸状乳頭がみられ, ご く僅かに茸状乳頭や大型円錐乳頭がみられた。SAMP $2 / \mathrm{Iw}$ の 2 力月齢では上皮細胞の配列がやゃ不規則とな り, 上皮突起と乳頭の配列も不規則なところがみられた。 その上, 上皮細胞の一部には比較的大きな核をもつ胞体 の明るい細胞からなる限局性の変化が認められた（Fig. $2-\mathrm{B}$, 矢印)。SAMR $1 / \mathrm{Iw}$ の 16 力月齢では上皮細胞の配 

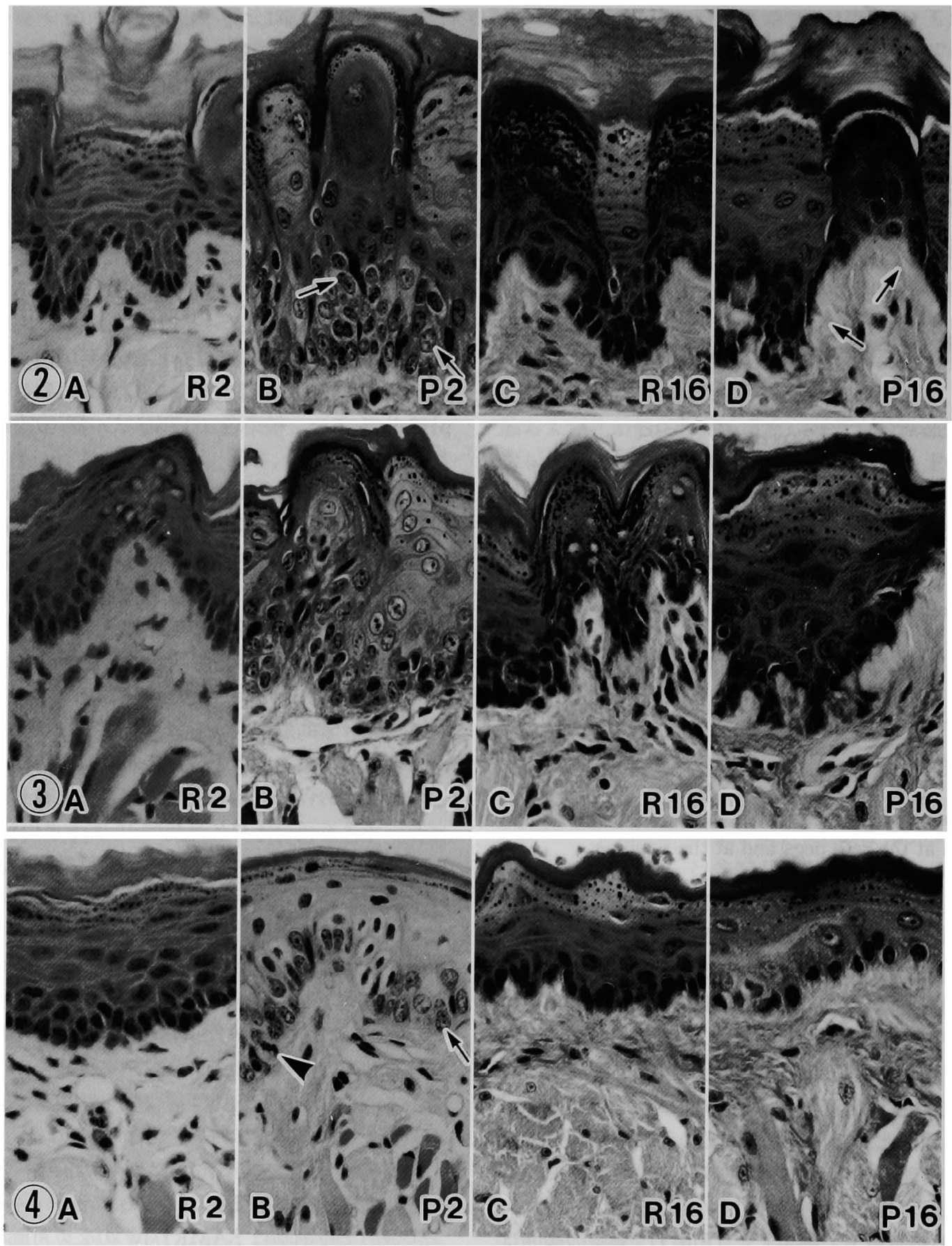

Fig. 2 Histology of the dorsal tongue epithelium. H \& E stain, $\times 340$.

A : SAMR1/Iw, 2 months of age. B : SAMP2/Iw, 2 months of age. Focal changes of the epithelial cells are seen (arrows). C : SAMR1/Iw, 16 months of age. D : SAMP2/Iw, 16 months of age. Extensive amyloid deposition beneath the epithelium (arrows).

Fig. 3 Histology of the lateral tongue epithelium. H \& E stain, $\times 340$.

A : SAMR1/Iw, 2 months of age. B : SAMP2/Iw, 2 months of age. C : SAMR1/Iw, 16 months of age. $\mathrm{D}: \mathrm{SAMP} 2 / \mathrm{Iw}, 16$ months of age.

Fig. 4 Histology of the ventral tongue epithelium. $\mathrm{H} \& \mathrm{E}$ stain, $\times 340$.

A : SAMR1/Iw, 2 months of age. B : SAMP2/Iw, 2 months of age. Focal change of epithelial cell (arrow) and mitosis are seen (arrowhead). C : SAMR1/Iw, 16 months of age. D : SAMP2/Iw, 16 months of age. 


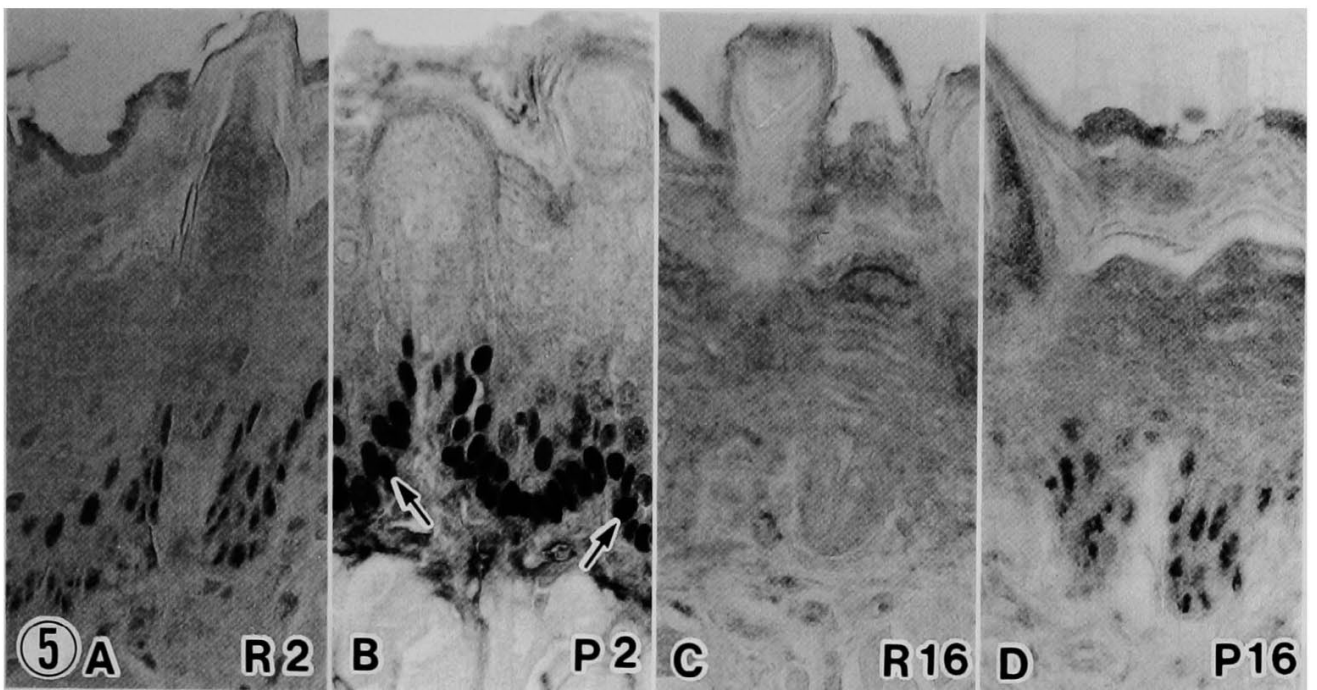

Fig. 5 PCNA immunostaining of the dorsal tongue epithelium. $\times 340$.

A : SAMR1/Iw, 2 months of age. B : SAMP2/Iw, 2 months of age. Many PCNA positive cells located at the basal and suprabasal layer (arrows). C : SAMR1/Iw, 16 months of age. D : SAMP2/Iw, 16 months of age.

列，上皮突起や乳頭の配列などは概ね規則的であり，上 皮細胞の萎縮などの変化はみられなかった（Fig. 2C)。一方, SAMP2/Iwの 16 力月齢では上皮直下に帯状 にアミロイドが大量に沈着し（Fig. 2-D, 矢印)，上皮突 起と乳頭の配列はやや不規則であった。

舌側縁の上皮細胞は舌背のそれとそれぞれ概ね同様の 所見であった（Fig. 3-A〜D）。舌下面の上皮細胞では $\mathrm{SAMR} 1 / \mathrm{Iw}$ の 2 力月歯では上皮突起の形成はみられな かった (Fig. 4-A)。また, SAMP2/Iw の 2 力月齢では 上皮突起が少数認められた（Fig. 4-B)。また，上皮基底 部の細胞の胞体は比較的大きく, 明るい大きな核を有し (Fig. 4-B, 矢印)，一部に分裂像もみられた (Fig. 4-B, 矢 頭)。SAMR1/Iw と SAMP2/Iw の 16 カ月齢ではそれ ぞれ舌背および舌側縁の上皮細胞と同様な所見であった (Fig. 4-C，D)。また, SAM の両系統において雌雄によ る形態的な差はみられなかった。

\section{2. 免疫組織化学的所見}

PCNA は舌粘膜上皮細胞の核に陽性であり，その染色 性は強陽性のものから弱陽性のものまでみられた（Fig. 5)。核の染色性では均一に染色されるものと微細顆粒状 を呈するものがみられたが，いずれの染色態度のものも 強陽性ないし中等度陽性の核を PCNA 陽性細胞と判定 した。PCNA 陽性細胞は粘膜上皮の基底層および基底層 上層に局在していた。さらに, 上皮突起部の上皮細胞に 陽性細胞は多く, 乳頭部の上皮細胞には陽性細胞が少な
かった (Fig. 5-B, 矢印)。SAMR1/Iw ではすべての月齢 群で PCNA 陽性細胞数は少なかった。一方, SAMP $2 / \mathrm{Iw}$ では 2 力月齢で陽性細胞が非常に多く,このような 所見は舌背, 舌側緑, 舌下面の 3 部位とも同様の傾向を 示していた。 2 カ月齢以外の SAMP2/Iw では PCNA 陽 性細胞数は少なかった。

\section{3. 組織計量的所見}

舌背の上皮突起数は $\mathrm{SAMR} 1 / \mathrm{Iw}$ では 1 カ月と 6 カ月 齢でやや少ないが，それ以外ではどの月齢でも約 15 個/mm であった (Fig. 6, 上段)。一方, SAMP2/Iw で は 2 カ月と 16 力月齢で約 18 個と他の月齢群よりも多 かった。舌側縁では上皮突起数は SAMP $2 / \mathrm{Iw}$ が 12 力月 齢を除いて SAMR1/Iw より多く, 特に 2 カ月齢では SAMR1/Iw との間に有意差がみられた（Fig. 6, 中段, $\mathrm{p}<0.05)$ 。舌下面の上皮では SAMR1/Iw は 6 カ月齢の 1 個を除いてどの月齢群でも上皮突起の形成はみられな かったが, SAMP2/Iw では上皮突起が形成されており， 特に 2 カ月と 16 カ月齢では SAMR $1 / \mathrm{Iw}$ との間に有意 差がみられた（Fig.6，下段， $\mathrm{p}<0.05 ） 。$

舌粘膜上皮の乳頭数は両系統とも加龄に伴う変化は明 瞭ではなく, 舌背では約 8 個であり, 舌側縁では約 5 個 であった（Fig. 7)。

舌粘膜上皮の厚さは上皮突起部では両系統とも加齢に よっても大きな変化はなく (Fig. 8), 舌背では約 $85 \mu \mathrm{m}$, 舌側縁では 50 から $60 \mu \mathrm{m}$, 舌下面では約 $40 \mu \mathrm{m}$ であっ 

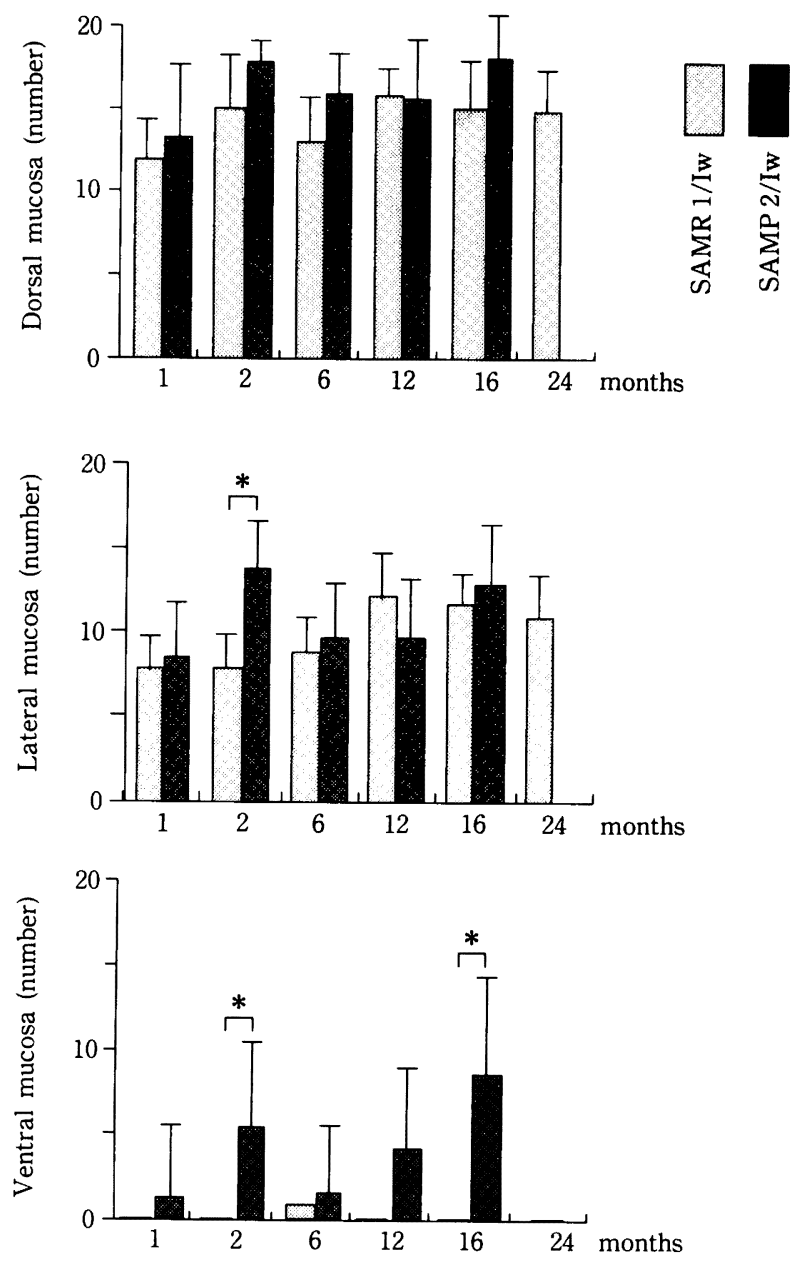

Fig. 6 Number of rete pegs per $1.0 \mathrm{~mm}$ length of epithelium in the middle portion of tongue of SAM. $\left({ }^{*} \mathrm{p}<0.05\right.$, ANOVA)

た。しかし， 3 部位とも 2 カ月と16力月齢では SAMP $2 / \mathrm{Iw}$ が SAMR $1 / \mathrm{Iw}$ より厚かった。特に舌背と舌下面 において 16 カ月齢では有意の差がみられた $(\mathrm{p}<0$. 05)。上皮乳頭部における舌粘膜上皮の厚さは両系統とも 加齢によってもほほ一定であり, 舌背で約 $50 \mu \mathrm{m}$, 舌側 縁で約 $30 \mu \mathrm{m}$, 舌下面で約 $20 \mu \mathrm{m}$ であった (Fig. 9)。

PCNA 陽性細胞数は個体間の変動が多いものの, 舌背 では SAR1/Iw の 1 から 24 力月齢まで加齢に伴う推移 はほとんど見られず，どの月齢群でも約 50 個 $/ \mathrm{mm}$ 以下 であった (Fig. 10)。しかし, SAMP2/Iw では 2 カ月齢 で約 230 個 $/ \mathrm{mm}$ と PCNA 陽性細胞が多く, 同月齢の $\mathrm{SAMR} 1 / \mathrm{Iw}$ との間に有意差がみられまた SAMP 2/Iw の他の月齢群との間にも有意差がみられた（Fig. $10, \mathrm{p}<0.01)$ 。舌側縁および舌下面における PCNA 陽性 細胞数は舌背とほほ同様の傾向を示しており, SAMP2/
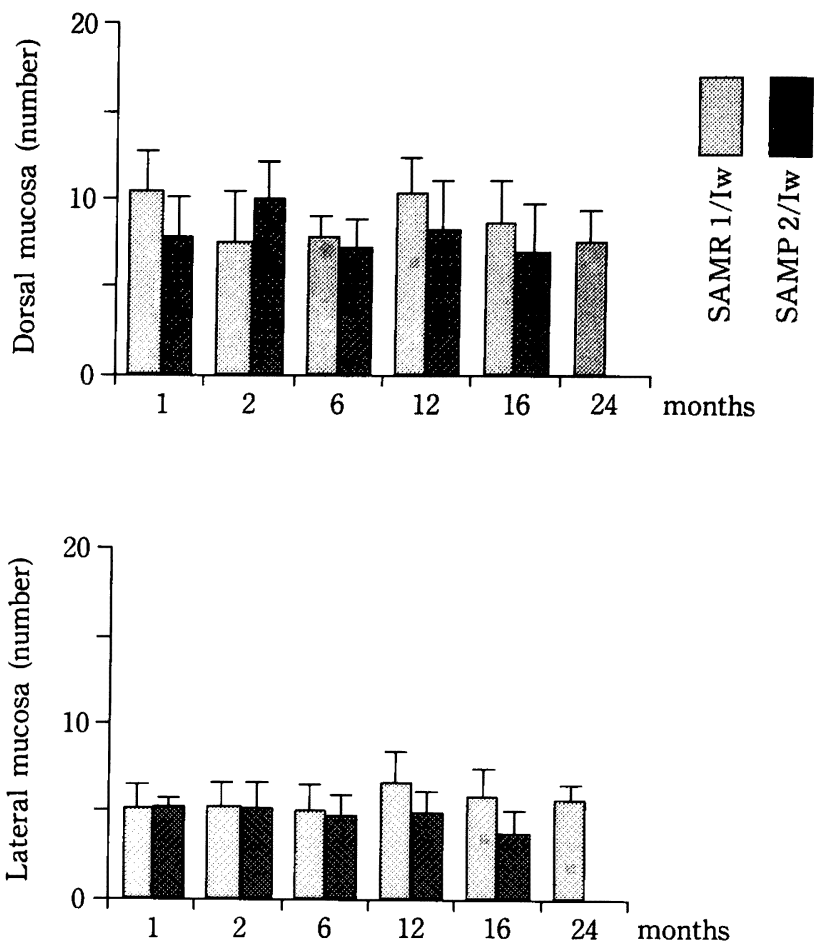

Fig. 7 Number of tongue papillae per $1.0 \mathrm{~mm}$ length of epithelium in the middle portion of tongue of SAM.

Iw の 2 カ月齢が他の月齢群より有意に多かった（Fig. 11, 12. $\mathrm{p}<0.01)$ 。

\section{考察}

老化促進モデルマウス (SAM) は遺伝的な促進老化症 とアミロイドーシスのモデル動物として開発された近交 系マウスで resistant 系 (SAMR) と prone 系 (SAMP) がそれぞれ数種類ずつある ${ }^{6 \sim 9)}$ 。SAMP は脱毛, 白内障, 脊柱湾曲などの種々の老化兆候が早期に好発し, 平均寿 命が短い。それに対して SAMR は老化兆候の程度は軽 く, その発生も遅く平均寿命は長い。SAMP に種々の促 進老化が遺伝的に現れる原因の詳細は十分に解明されて いないものの, これまでに以下のような染色体の異常が 報告されている。すなわち, 染色体外の環状 DNA が SAMP1 系において, SAMR2 系より早期に増幅されて 認められる9”。また, 骨髄細胞に扔ける染色体異常が SAMR1 より SAMP1に早期に, 高頻度にみられるとい う。これまで著者ら ${ }^{100}$ は, SAMR1/Iw と SAMP2/Iwを 用いて口腔領域の加齢変化を種々の観点から検索し, $\mathrm{SAMP} 2 / \mathrm{Iw}$ に何らかの成長促進因子あるいは逆に SAMR1/Iw に何らかの成長抑制因子がある可能性を示 

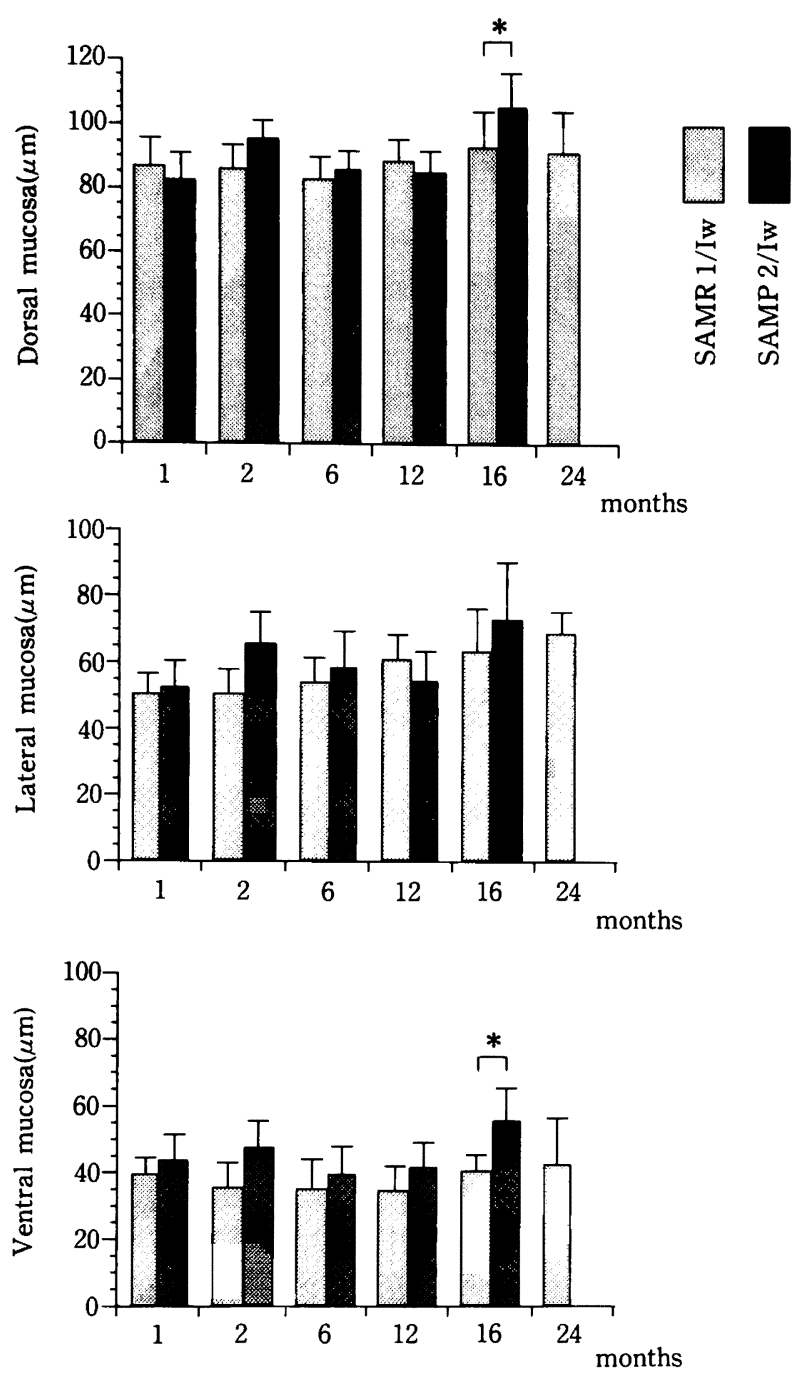

Fig. 8 Epithelial thickness at the rete pegs in the middle portion of tongue of SAM. $\left({ }^{*} p<0.05\right.$, ANOVA)

唆してきた。

通常の系統のマウスを用いた粘膜上皮の加齢変化に関 する研究は少ない ${ }^{19)}$ 。今回の SAM 舌粘膜の組織学的な 検索では SAMR1/Iw では加齢によっても上皮の扁平化 や上皮細胞の萎縮などの変化はみられなかった。しかし， SAMP2/Iw では 16 カ月齢群でアミロイドが沈着し, 上 皮突起と乳頭の配列がやや不規則であったが，これ以外 には顕著な変化はみられなかった。また, 後述の組織計 量学的所見からも SAM の両系統の 16 ないし 24 力月齿令 には老齢のヒトと平行した所見はみられなかった。さら にヒトの場合は個体差が大きく，また動脈硬化や炎症な どの病的老化現象がしばしばみられる2)。これに対して 実験用の小動物は飼料や他の飼育条件を一定にできる 他, 遺伝的な均一性, 多数を統計的に扱えるなどの利点
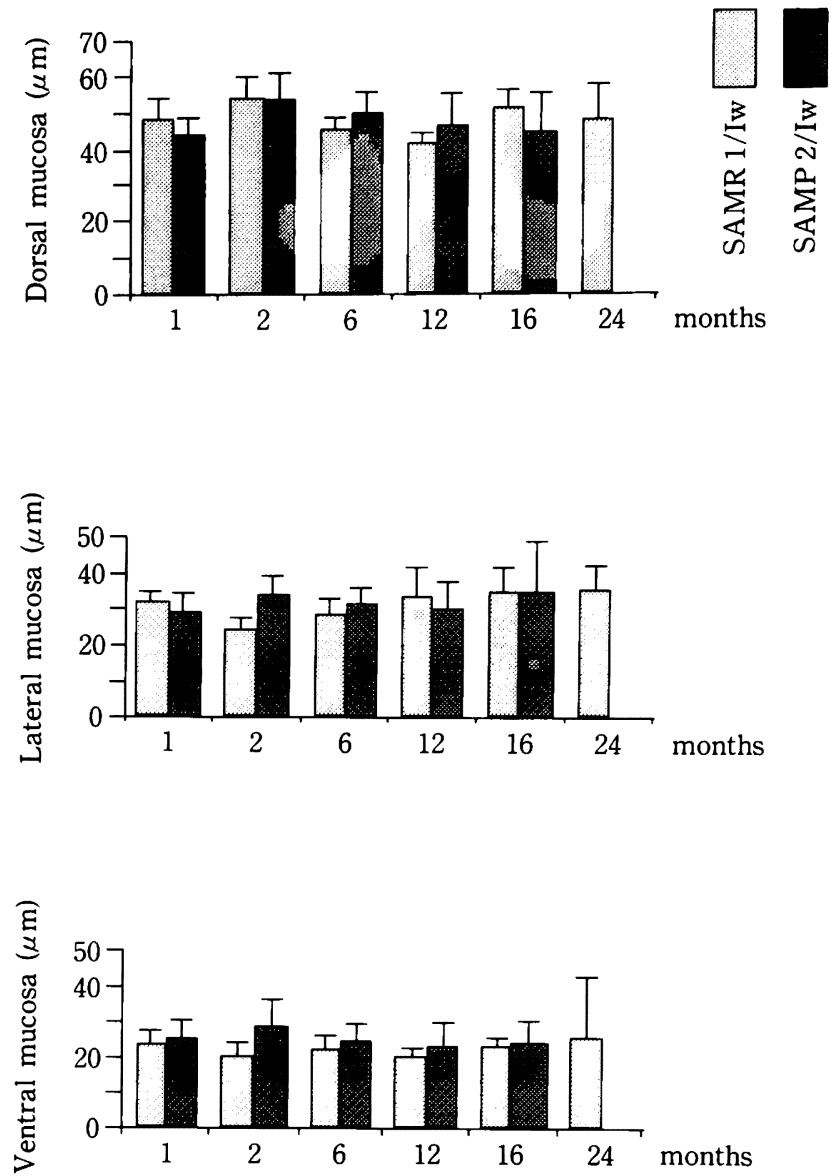

Fig. 9 Epithelial thickness at the papillae in the middle portion of tongue of SAM.

を持っている。特に他に自然発症の老化モデルがない現 在では老化兆候を早期に高度に自然発症する SAM のP 系とそれに対する対照群としてR系を用いて種々の加齢 変化を研究する意義は大きいと思われる。

呫粘膜のうち舌背粘膜は特殊粘膜に属し, 系状乳頭お よび茸状乳頭などが発達している ${ }^{13,20)}$ 。一方, 舌下粘膜は 上皮層が薄く, 角化の程度が低い被覆粘膜に属している。 また, 舌側緑はヒトにおいては舌癌の好発部位として知 られる。そこで今回の検索では舌の中央部において，舌 粘膜を舌背, 舌側縁, 舌下面の 3 部位に分けた。

上皮突起は上皮稜あるいは上皮釘脚とも呼ばれ，舌粘 膜においては舌背から舌側縁にかけて分布し，舌下面で は少ない20)。上皮突起と乳頭を形成する細胞の性質は異 なっていると考えられる。すなわち，上皮突起の細胞は 増殖能が高く，この部位の幹細胞から分裂した細胞が乳 頭部へ移動するといわれている21)。また,ケラチンや接着 分子の分布も異なっている ${ }^{22)}$ 。 SAMR1/Iw の舌粘膜で は上皮突起の数は加齢によっても一定であった。また， 


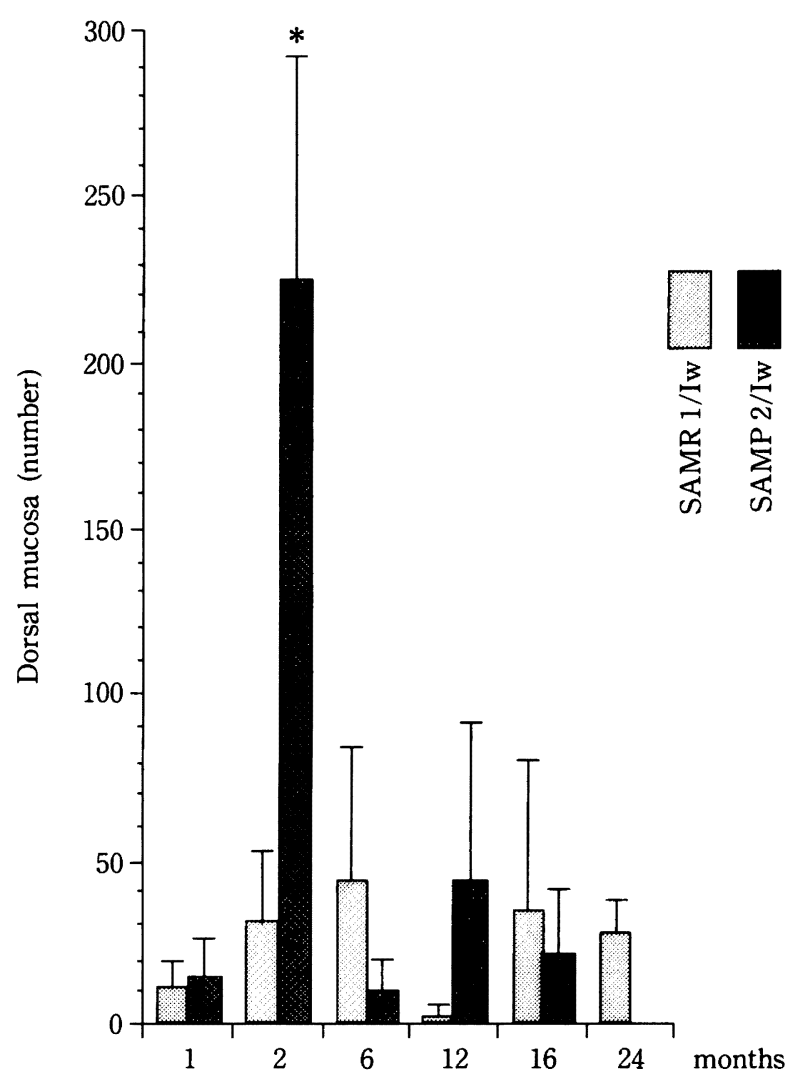

Fig. 10 PCNA positive cell number per $1.0 \mathrm{~mm}$ length of dorsal epithelium in the middle portion of tongue of SAM. $\left({ }^{*} \mathrm{p}<0.01\right.$, ANOVA)

$\mathrm{SAMP} 2 / \mathrm{Iw}$ の 2 カ月と 16 カ月齢において上皮突起の 数が多かった。

マウスの舌は舌の中程から後方にかけて舌隆起部があ る。今回の検索は舌隆起部の始まり付近で前額断してお り,この付近には糸状乳頭, 咠状乳頭, 大型円錐乳頭が 存在する ${ }^{23)}$ 。これらの舌乳頭はヒトでは加齢1やや糖尿病な ぞの病的状態24)で萎縮したり，減少したりする。しかし， 今回の SAM の両系統の検索で得られた舌乳頭数は加齢 によっても明瞭な変化がみられなかった。

舌粘膜上皮の厚さは SAMR1/Iw の場合は上皮突起部 でも乳頭部でも加齢による変化はみられなかった。しか し, SAMP $2 / \mathrm{Iw}$ では上皮突起部の上皮は 2 力月と 16 力 月齢において SAMR1/Iwより厚かった。 2 力月齢の $\mathrm{SAMP} 2 / \mathrm{Iw}$ では上皮突起部の上皮が厚いこと，上皮笑 起の数が多いことに加え, 後述の PCNA 陽性細胞数が 多い所見を考え合わせると， SAMP2/Iw の 2 力月齢で 上皮細胞の増殖能が高いことが示唆された。SAMP2/Iw の 16 カ月齢では粘膜固有層にアミロイドの沈着が高度 であり，これが上皮突起の形状を細長くし，この部位の 上皮を厚くし，また上皮突起数を増加させている大きな

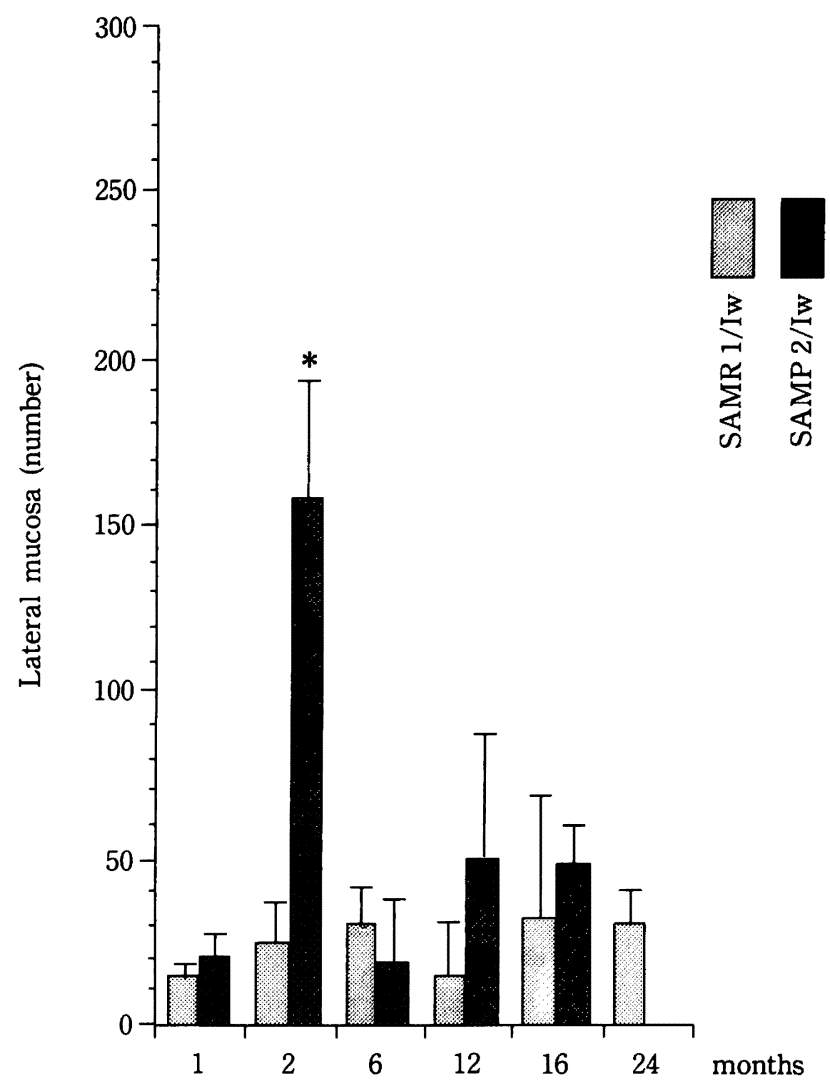

Fig. 11 PCNA positive cell number per $1.0 \mathrm{~mm}$ length of lateral epithelium in the middle portion of tongue of SAM. $\left({ }^{*} p<0.01\right.$, ANOVA $)$

要因と思われる。

口腔粘膜が加齢とともに薄くなる原因の 1 つとして上 皮細胞の増殖能が減少することが考えられる。細胞増殖 の研究には古典的には分裂像を数えたり， ${ }^{3} \mathrm{H}-$ サイミジ ンでラベルする方法が用いられてきた。ヒトおよび実験 動物を用いた ${ }^{3} \mathrm{H}$-サイミジンによる口腔粘膜上皮の細胞 増殖能の研究では, 加齢とともに増殖能が増加するとい う説 ${ }^{25,26)}$, 変わりがないという説27,28), そして減少すると

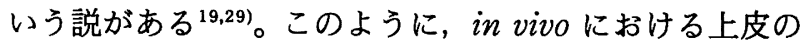
増殖能についての研究には統一した見解がみられな (213)。

最近, 細胞增殖能を検索するマーカーとして増殖細胞 核抗原 (PCNA) が開発された ${ }^{15,16,30)}$ 。PCNA は動物, 植物に共通するDNA 複製時に必須な核蛋白質であ $3^{30}$ 。PCNA の発現は腫瑒細胞増殖能の判定に用いられ ることが多いが15 17)，正常組織についての検索は少な

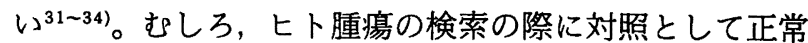
上皮が検索されており，この時の PCNA によるラベル 指数は約 $11 \%$ 程度である ${ }^{17)}$ 。ウサギの角膜上皮では基底

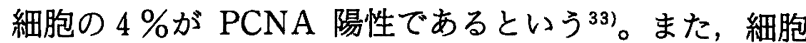




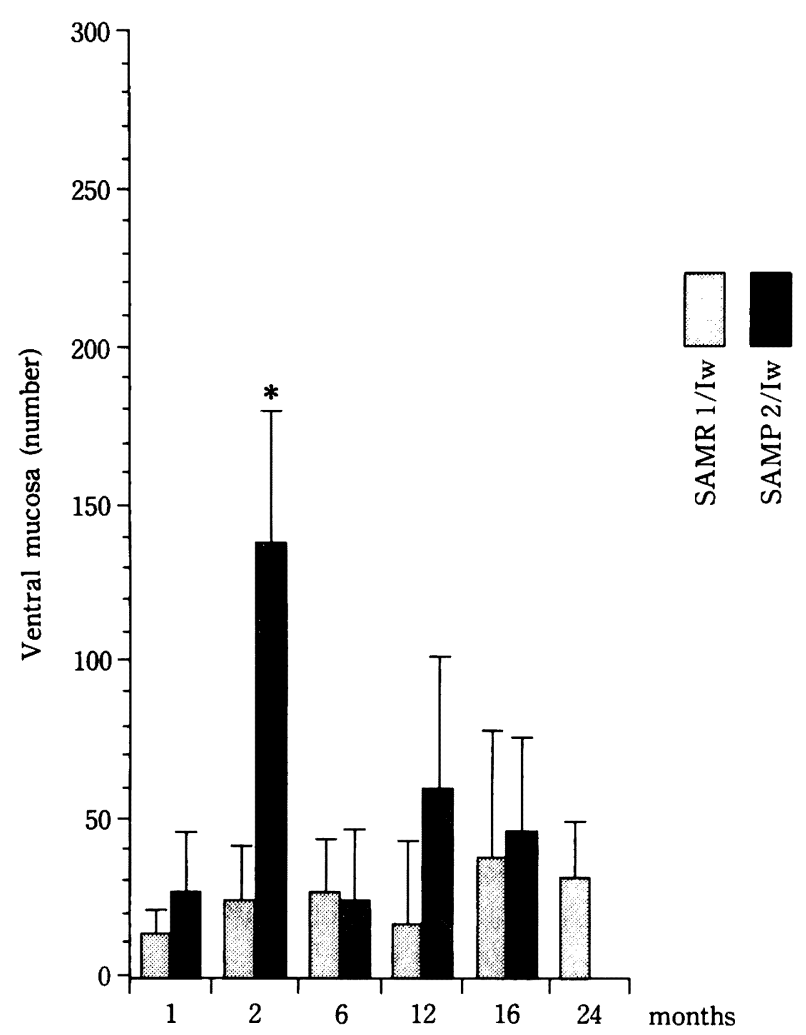

Fig. 12 PCNA positive cell number per $1.0 \mathrm{~mm}$ length of ventral epithelium in the middle portion of tongue of SAM. ( ${ }^{*} \mathrm{p}<0.01$, ANOVA)

増殖周期の S 期をラベルするものに Bromodeoxyuridine (BrdU) があり, BrdU を用いたハムスターの正常 上皮の in vivo のラベル指数は $6 \%$ 程度である ${ }^{34)}$ 。

In vivo の細胞增殖能に関しては口腔粘膜上皮のそれ は皮成と腸粘膜の中間と報告されている ${ }^{21}$ 。PCNA を用 いた細胞増殖能の加齢変化に関する研究は少なく, マウ スの腸上皮の場合, 加齢によっても一定であるという311。 同様に, ヒト正常角化細胞でも不変であるという ${ }^{32)}$ 。しか し, in vitro ではヒト培養細胞で, 老齢期には蛋白質レ ベルでも mRNA レベルでも PCNA 発現は滅少するこ とがわかっている35)。さらに, Werner's 症候群では PCNA 蛋白発現の減少速度が正常の人に比べて $5 \sim 6$ 倍高いという ${ }^{36)}$ 。

今回の SAM の舌粘膜の研究では PCNA 陽性細胞数 は SAMR1/Iw では加齢によっても変化はなく，また， SAMP2/Iw でも 2 カ月齢を除けば一定であった。この 結果は in vivo の系では加齢によっても口腔粘膜上皮細 胞の増殖能は変化がないという説27,28)を支持している。 しかし, SAMP2/Iw の 2 カ月齢ではほとんどの基底細 胞が PCNA 陽性を示し, その数も多く, 約 230 個 $/ \mathrm{mm}$
という結果が得られた。このことから $\mathrm{SAMP} 2 / \mathrm{Iw}$ の 2 カ月齢では細胞の增殖能が高い可能性が考えられた。

最近, PCNA の染色性については, いくつかの疑問点

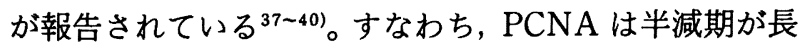
いことが知られ，必ずしも ${ }^{3} \mathrm{H}-$ サイミジンラベルによる

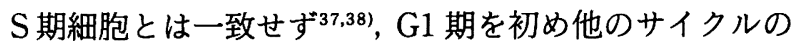
細胞も染まるという。また, PCNA が強陽性の細胞は $\mathrm{S}$ 期細胞を現し，弱陽性や顆粒状のものがそれ以外のもの という説もある ${ }^{37)}$ 。さらに, 最近の報告ではヒトの腫湯周

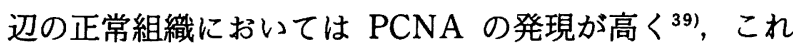
は増殖期の細胞以外に腫場の発生する $\mathrm{EGF}$ p $\mathrm{TGF} \beta$ などの成長因子による PCNA 発現の誘導がみられるた めという ${ }^{40)}$ 。

SAMP2/Iw の 2 カ月齢では上皮細胞には比較的大き な核をもつやや大きな細胞の増加が認められ，また，上 皮突起数が多く, 上皮突起部に扔ける上皮が厚く, PCNA 陽性細胞が多かった。これらの所見からこの月齢 の SAMP2/Iw の舌粘膜上皮細胞は細胞増殖が六進して いる可能性が推察された。SAMP2/Iw において若齢時 に細胞増殖が穴進することと老化兆候が早期に高度に出 現することとの関連性には興味が持たれる。一方で，2 カ月齢で何らかの成長因子が影響している可能性も除外 できないと思われた。

\section{結 論}

老化促進モデルマウス (SAM) の舌粘膜上皮の加齢的 変化の解明を目的に実験群として SAMP2/Iw, 対照群 として SAMR1/Iw の舌を検索し，以下の結論を得た。

1. 組織学的に SAMR1/Iw には加齢によっても舌粘 膜上皮に変化がなかったが, SAMP2/Iw では 2 力月齢 で上皮細胞に比較的大きな核をもつやや大型の細胞の増 加が認められた。また，16 カ月齢では上皮下にアミロイ ドの沈着がみられた。

2. 呫粘膜の上皮突起数は 2 力月と 16 力月齢群で $\mathrm{SAMP} 2 / \mathrm{Iw}$ が SAMR1/Iw より多かった。特に 2 カ月 齢では舌側縁と舌下面で有意差がみられ，16 カ月齢では 舌下面で有意差がみられた $(\mathrm{p}<0.05)$ 。

3. 舌乳頭数は SAMP $2 / \mathrm{Iw}$ と SAMR $1 / \mathrm{Iw}$ の両系で 加齢による変動はなかった。

4. 舌粘膜上皮の厚さは上皮突起部では 2 カ月と 16 カ月歯で SAMP2/Iw が SAMR1/Iw より厚かった。特 に 16 カ月齢では舌背と舌下面で有意差がみられた（ $\mathrm{p}<$ $0.05)$ 。上皮乳頭部では両系統とも舌粘膜上皮の厚さは加 歯によっても一定であった。 
5. PCNA は舌粘膜上皮の基底層ないし基底上層の 細胞の核に陽性であった。SAMR1/Iw では加齢によっ ても陽性数が一定であったが， SAMP2/Iw では 2 力月 齢で約 230 個 $/ \mathrm{mm}$ と多く, 2 力月齢以外は加齢によっ ても一定であった。 2 カ月齢では $\mathrm{SAMP} 2 / \mathrm{Iw}$ と $\mathrm{SAMR} 1 / \mathrm{Iw}$ の間に有意差があり, また SAMP2/Iw に おいては 2 カ月齢と他の月齢群の間にも有意差がみられ た $(\mathrm{p}<0.01)$ 。

6. 以上の組織学的および免疫組織学的所見の背景と して SAMP2/Iw の 2 力月齢では上皮細胞の細胞増殖能 が高いか, 何らかの成長因子が影響している可能性が推 察された。

7. 老化促進モデルマウス（SAM）は口腔諸組織の加 齢変化の研究に有用なモデルと考えられた。

本稿を終えるにあたり，ご愳篤な指導と校閲を賜りまし た岩手医科大学歯学部口腔病理学講座 佐藤方信教授に深 甚なる謝意を表します。また, 本研究を行うにあたって種々 のご指導とご援助をいただいた同口腔病理学講座の諸先生 方と貴重なご示唆をいただいた本学中央写真室と中央電顕 室に深謝いたします。

本論文の要旨の一部は第 37 回歯科基礎医学会学術大会 (平成 7 年 9 月 23 日, 東京都) および岩手医科大学歯学会 第 42 回例会 (平成 8 年 7 月 6 日, 盛岡市) において発表し た。

\section{文献}

1）石川梧朗, 秋吉正豊：II. 口腔粘膜の病変，A．年 齢的変化, 口腔病理学 II. 2 版, pp. $44 \sim 47$, 永末書 店, 京都, 1982 .

2）佐藤方信, 鈴木鍾美: 加齢と病変一舌. 歯界展望 59: 743 749, 1982.

3) Satoh, M., Sashima, M. Itagaki, M. and Suzuki A. : Quantitative age changes of the histological constituents of the human tongue. Jpn. J. Oral Biol. 28 : 746 751, 1986.

4）佐藤方信, 佐島三重子, 畠山節子, 大津匡志, 鈴木 鍾美：ヒト舌粘膜上皮の組織学的, 免疫組織化学的 研究. 口科誌 $39 ： 336 \sim 342,1990$.

5）佐藤方信, 吉村法子, 大島 忍, 菊池博生, 鈴木鍾 美：ヒト舌粘膜上皮におけるランゲルハンス細胞数 とその分布．歯基礎誌 $34 ： 120 １ 25 ， 1992$.

6) Takeda, T., Hosokawa, M., Takeshita, S., Irino, M., Higuchi, K., Matsushita, T., Tomita, Y., Yasuhira, K., Hamamoto, H., Shimizu, K., Ishii, M. and Yamamuro, T. : A new murine model of accelerated senescence. Mech. Ageing Dev. 17 :
183 194, 1981.

7) Takeda, T., Hosokawa, M. and Higuchi, K.: Senescence-accelerated mouse (SAM) : A novel murine model of accelerated senescence. J. Amer. Geriatr. Soc. 39 : 911 919, 1991.

8）桶口京一, 内木宏延, 細川昌則：老化促進モデルマ ウス $(\mathrm{SAM})$, (杉山武敏編), 疾病の分子機構, $\mathrm{pp}$. 492 496, 文光堂, 東京, 1993.

9) Takeda, T., Hosokawa, M. and Higuchi, K. : Senescence accelerated mouse (SAM). A novel murine model of aging. In: The SAM Model of Senescence. (edited by Takeda, T.), pp. 15 22, Excerpta Medica, Amsterdam, 1994.

10) Sashima, M. and Satoh, M. : Age-related changes of the periodontal tissues in senescence accelerated mouse (SAM). In : The SAM Model of Senescence. (edited by Takeda, T.), pp. 223 226, Excerpta Medica, Amsterdam, 1994.

11) Sashima, M., Satoh, M. and Suzuki, M. : Oral senile amyloidosis in senescence accelerated mouse (SAM). J. Oral Pathol. Med. $19:$ 381 384, 1990.

12）佐藤方信，佐島三重子，板垣光信，守田裕啓，鈴木 鍾美：老化促進モデルマウス（SAM-P/2）の舌動 脈に認められた微細顆粒状物質. 歯基礎誌 28 : 466 471, 1984.

13） Squier, C. A. and Hill, M. W. : 18 章 口腔粘膜. 構造の変異, (Ten Cate, A. R. 著, 平井五郎他訳), 口腔組織学, pp. 458 465, 医歯薬出版, 東京, 1989.

14) Hill, M. W. : Cell renewal in oral epithelia. In : The structure and function of oral mucosa. (edited by Meyer, J., Squier, C. A. and Gerson, S. J.), pp. 53 81, Pergamon Press, Oxford, 1984.

15）佐々木功典, 黒瀬 顕：増殖細胞抗原とその応用 病理と臨床 $12: 97 \sim 102,1994$.

16）松野吉宏, 向井 清: 增殖細胞核抗原 (PCNA). 病 理と臨床 $9: 879 \sim 883,1991$.

17）岩井正行, 姚 立, 古田 勲：舌扁平上皮癌の增 殖細胞核抗原 (PCNA) による免疫組織化学的検 討. 日口外誌 $40: 1 \sim 5,1994$.

18）堤 寛：第 2 部，第 2 章 パラフィン切片による 光顕的醅素抗体法染色. pp. 99 141, (渡辺慶一, 中 根一穂編）酔素抗体法 一巻 改訂三版, 学際企画, 東京, 1992.

19) Cameron, I. L. : Cell proliferation and renewal in aging mice. J. Gerontol. $27:$ 162 172, 1972.

20）藤田尚男, 藤田恒夫：III.消化器系 A. 口腔壁の組 織, 標準組織学, 各論 3 版 pp. 78 83, 医学書院, 東 京, 1992 
21) Hume, W. J. and Potten, C. S. : Advances in epith elial kinetics-An oral view. J. Oral Pathol. 8 : 3 22, 1979.

22）古谷野浩美，神部芳則，野口忠秀，赤坂庸子，矢尾 板英夫：ヒト正常舌背部粘膜上皮におけるケラチン および接着分子の発現状態. 口科誌 $44: 596 〜 602$, 1995.

23）小林 寛, 宮田 建, 高橋啓一, 岩崎信一：マウス 舌の結合織乳頭の三次元構造. 解剖誌 64: 523 528, 1989.

24) Akiya, O., Serizawa, N., Sugihara, M., Katagiri, S. and Kawashima, Y.: A histological study of changes in the lingual papillae of streptozotocininduced diabetic rats. Bull. Tokyo dent. Coll. 33 : 13 24, 1992.

25) Toto, P. D., Rubinstein, A. S. and Gargiulo, A. W. : Labeling index and cell density of aging rat oral tissues. J. Dent. Res. 54: 553 556, 1975.

26) Hill, M. W. : Changes in rat palatal epithelium during neonatal growth. Anat. Rec. 199:129 $\sim 137,1981$.

27) Hornstein, O.P. and Schell, H. : Comparative study on the ${ }^{3} \mathrm{H}$-thymidine index of dorsal epidermis, buccal mucosa, and seminal vesicles in senile male rats. Arch. Dermatol. Res. $254: 37 \sim 41,1975$.

28) Maidhof, R. and Hornstein, O. P. : Autoradiographic study on some proliferative properties of human buccal mucosa. Arch. Dermatol. Res. 265 : 165 172, 1979.

29) Sharav, Y. and Massler, M. : Age changes in oral epithelia. Progenitor population, synthesis index and tissue turnover. Exp. Cell Res. $47: 132 \sim 138$, 1967.

30) Nakane, P. K., Moriuchi, T., Koji, T., Taniguchi, Y., Izumi, S. and Hui, L. : Proliferating cell nuclear antigen (PCNA/cyclin): Review and some new findings. Acta Histochem. Cytochem. 22: 105 116, 1989.

31) Morita, T., Usuda, N., Hanai, T. and Nagata, T. : Changes of colon epithelium proliferation due to individual aging with cyclin proliferating cell nuclear antigen (PCNA/cyclin) immunostaining compared to ${ }^{3} \mathrm{H}$-thymidine radioautography. His- tochem. $101: 13 \sim 20,1994$.

32) Tu, P., Miyauchi, S. and Miki, Y. : Age-related proliferative activity in dermal melanocytic naevi detected by PCNA/cyclin expression. Brit. J. Dermatol. 129 : 65 68, 1993.

33）山田昌和, 真島行彦: 創傷治撚過程における角膜上 皮基底細胞の增殖, 分化動態. 日眼会誌 $99: 10 \sim 16$, 1995.

34）新谷 悟：実験的舌癌形成に関する研究．第 2 編 細胞動態ならびに癌遺伝子産物に関する免疫組織化 学的検討. 岡山歯誌 11:47 61, 1992.

35) Stewart, C. A. and Dell'orco, R. T. : Age related decline in the expression of proliferating cell nuclear antigen in human diploid fibroblasts. Mech. Ageing Dev. 66 : 71 80, 1992.

36) Kill, I. R., Faragher, R. G. A., Lawrence, K. and Shall, S. : The expression of proliferation-dependent antigens during the lifespan of normal and progeroid human fibroblasts in culture. J. Cell Sci. $107:$ 571 579, 1994.

37）辻 龍雄, 佐々木功典, 木村由香, 前田寛治, 金川 昭啓, 井上 敬, 早津良和, 篠崎文彦: 增殖細胞核 抗原 (PCNA) の免疫組織染色における問題点. 日 口外誌 $38: 21 \sim 24,1992$.

38) Scott, R. J., Hall, P. A., Haldane, J. S., Van Noorden, S., Price, Y., Lane, D. P. and Wright, N. A. : A comparison of immunohistochemical markers of cell proliferation with experimentally determined growth fraction. J. Pathol. $165: 173 \sim 178$, 1991.

39) Hall, P. A., Levison, D. A., Woods, C., Yu, C-W., Kellock, D. B., Watkins, J. A., Barnes, D. M., Gillett, C. E., Camplejohn, R., Dover, R., Waseem, N. H. and Lane, D. P. : Proliferating cell nuclear antigen (PCNA) immunolocalization in paraffin sections : an index of cell proliferation with evidence of deregulated expression in some neoplasms. J. Pathol. 162 : 285 294, 1990.

40) Hall, P. A., Coates, P. J., Goodlad, R. A., Hart, I. R. and Lane, D. P. : Proliferating cell nuclear antigen expression in non-cycling cells may be induced by growth factors in vivo. Br. J. Cancer 70:244 247, 1994. 